\title{
Limiting the Objectives of the Course in Instruction in Library Use
}

\section{Mr. Sprague is librarian, Tuskegee Insti-} tute.

$T_{\text {he literature dealing with instruc- }}^{\text {he }}$ $\mathcal{I}_{\text {tion }}$ in the use of libraries is fairly extensive, although it is essentially repetitious in character. Despite innumerable individual variations most such courses deal with the arrangement of the library, sometimes featured or initiated by a tour; the card catalog; the loan system; and reference tools. They are usually offered to freshmen, during the first part of the school year. Exigencies of the local situation take over at this point. These courses are not always required, and when required seldom yield course credit if they are offered as independent courses. They are frequently conducted by members of the library staff. However, it is not at all unusual to find this instruction given as part of another course. Young states that of 88 colleges and universities, replying to a questionnaire, 35 combined the library instruction with English, and 7 offered it "in connection with social sciences, education and statistics."

Variations in the content of this instruction constitute an interesting commentary on the thinking of those who offer it, although this statement is not to be construed as a plea for standardization. One teachers college has stressed bibliographic abbreviations, ${ }^{2}$ along with the more standard

\footnotetext{
1 Young, A. Beatrice. "Let Us Teach Library Science in College." School and Society 50:837, Dec. 23, 1939. ducing the Larry R., and Pierson, Stella. "IntroHigher Education 10:448, November 1939.
}

units. One chief librarian has argued for the inclusion of an "understanding of the concept of the library as a social institution," plus some attention to the development of the modern library's emphasis on use as against storage. ${ }^{3}$

Variations in the length of time devoted to this instruction constitute, on the other hand, a commentary on the evaluation placed on it by faculty and administration. The range is from one hour to one hour a week for a semester. ${ }^{4}$ Possibly nowhere else in the area of college curricula will one find diversity to the extent that some colleges give twelve to fifteen times as much time, or more, to a course of instruction as do some others. It must not be forgotten, of course, that many institutions of higher learning do not provide any formal instruction.

\section{Objectives}

In the light of these variations it has seemed worth while to determine what its common objectives are, and what they should be. The average characteristics of the course the writer has in mind are as follows: (I) it is offered to all freshmen, or to those receiving unsatisfactory scores on a qualifying test; (2) it is taught either by the library staff or by librarians and faculty members jointly; (3) it is offered as a separate course or as a part of another course. If we begin with the question of the necessity for such a course we seem to

\footnotetext{
${ }^{3}$ Smith, Leland R. "Teaching the Use of the Library." Journal of Higher Education 7:96-97, February, 1936.

'See Young, op. cit., 837 .
} 
be on firm ground. A majority of librarians profess that the students of their colleges require it. That the faculties of many of these institutions share in part this belief is indicated by the fairly large number of them that have permitted the offering of this instruction. Whether these same faculties are in agreement as to its relative merits is another question altogether, as is seen by the striking disparity in allotments of time accorded it. ${ }^{5}$

It is obvious that the nature of the individual situation-such as the training and background of its students, objectives, curriculum, the resources, arrangement, and personnel of the library, and the facultyshould determine how and at what length such a program should be conducted. It seems equally obvious that, once the program in library orientation has received institutional approval, adequate provisions of time and instructional personnel should be made, whether it is conducted as an independent entity or as a part of an already established course offering. The answer to this will be in the practiced, rather than the professed objectives of the institution.

\section{Student Reaction}

It should be noted further that the belief in the existence of this need stands despite the fact that perhaps comparatively greater attention has, during the past 25 years, been given to instruction in library use on the elementary and secondary school level than on the collegiate. It is not altogether clear whether this bespeaks failure on the part of the former. If this is the case, it would seem to be due either to a lack of skill on the part of many teachers engaged in it, or to the lack of generally accepted underlying principle, or to both. ${ }^{6}$ Student reaction

1 Ibid.

6 Alexander, Carter. "Cooperation in Teaching Elementary-School Pupils to Use Library Materials." offers some kind of answer to the question. Webb has pointed out that freshmen in an Eastern college who had had instruction in high school library use did not remember having had it, this being perhaps the most notable example of a Freudian error recorded in library literature. ${ }^{7}$ To some college students the college-offered instruction has seemed a needless duplication of previous teaching, although ways of combating this reaction have been suggested. ${ }^{8}$ Reed's analysis of the library use of 464 freshmen (along with 66 sophomores, 68 juniors, and 52 seniors) suggests some degree of inefficacy in this work in elementary and high schools. ${ }^{9}$ She states, for example, that "the results of a diagnostic test on knowledge of well-known encyclopedias show a striking lack of specific knowledge of these books and an inability to associate certain types of questions with the most likely sources of information. Need of detailed instruction and more assistance in the utilization of such reference tools is clearly indicated." 10 Relevant conclusions of this study are as follows:

Students have not acquired specific and detailed knowledge of reference tools such as dictionaries and encyclopedias.

Students have not learned to use parts of books effectively and have inadequate knowledge of bibliographic features such as footnotes, bibliographies, and indexes.

Students are not able to evaluate sources of information readily. ${ }^{11}$

On the other hand, it has been suggested that the lower-level instruction provides a helpful background. Feagley believes that

Elementary School Journal 39:452-59, February 1939; also his "Criteria for Evaluating Instruction in the Use of Library Materials." Elementary School Journal 40:269-76, December 1939.

7 Webb, Helmer L. "Bibliographic Course for the Pre-Graduate Student." Library Journal 63:402, May I 5 , 1938 .

Young, A. Beatrice. "The Freshmen-Our Oprtunity." Library Journal 62:235, Mar. 15, 1937. 9 Reed, Lula Ruth. "Do College Students Need Reference Service?" Library Quarterly 13:232-40, July 194.3 .

${ }_{10}$ I bid., 233.

11 Ibid., 240. 
"the increasing use of the school library at the elementary - and secondary - school levels is sending an ever growing number of students to college with some knowledge of how to use library resources. This is enabling the college to plan its courses and other devices for instructing students in library use with a degree of success hitherto impossible" (italics mine). ${ }^{12}$ Even if we may assume that the latter view is the more tenable, the marked deterioration of teaching caliber during the war and the first postwar years, plus swelling college enrolments, indicates that this aspect of the problem will hardly find an early solution. ${ }^{13}$ It should be pointed out, however, that these two views are not necessarily contradictory. It is probable that, however large the shortcomings of elementary and secondary school instruction in library use have been, the absence of such instruction would have made for a far more disturbing situation.

\section{Value of Course Instruction}

On the question of the value of course instruction in meeting the need just described, there is also a nearly unanimous sentiment. For the most part, we have to rely on the testimony of those librarians reporting that they have observed improvement, the most frequent touchstone being the compilation of a bibliography. It is not uncommon to use paper and pencil tests to measure the degrees of achievement. Meyering and Pierson, for example, report a median score (40 freshmen as subjects) of 89 on an achievement test as compared with a median of 69 on the diagnostic. ${ }^{14}$ After two weeks' study, a group of juniors

12 Feagley, Ethel M. "Preparation of Teachers for Effective Library Use." Forty-second Yearbook of the National Society for the Study of Education. Part II. Chicago, Department of Education, University of Chicago, 1943. p. 303.

${ }_{13}$ Dummer, E. Heyse. "The Library Method Course in the Post-War Era." Bulletin of the American As. sociation of College Professors 32:325, Summer 1946.

14 Meyering and Pierson, op. cit., 449. tested by Deer increased their mean score on the Peabody Test from 47.9 to 97.5, a difference of 49.6 , with a critical ratio of 20.2. ${ }^{15}$

If the worth of this instruction be admitted, it follows that the establishment and articulation of its objectives are a matter of primary importance. The articulation of clear and feasible objectives offers at least two much-needed results. One of them is a more satisfactory placement of emphasis on the parts of instruction. For example, one of the best analyses of this subject that the writer has seen, after recommending that one hour out of eighteen be given to bibliography, affirms that the compilation of a bibliography is perhaps the most effective way of testing students at the end of the course. The second result will be a tightly knit plan that can be presented to a faculty with some hope of wholehearted acceptance. Moreover, the soundness of the objectives is perhaps as important a basis for evaluation as the skill with which they are realized. They are four-fold and are listed here in probable order of frequency:

I. To increase students ability to locate the material they need.

2. To extend their knowledge of useful library tools.

3. To encourage them to make extensive use of the library.

4. To give them rudimentary knowledge of correct study methods.

Smith has recommended a fifth objective, although it may be questioned whether the type of instruction with which this paper is concerned is in any way the proper instrument for its attainment:

The aim .... is to show the place of library service in modern life, to indicate the part it

15 Deer, George H. "The Peabody Library Information Test: a Study of Its Statistical Validity and Re liability." Journal of Experimental Education 9:234, March I94I. 
plays in education in a democracy. Statistics as to the cost of such service, pointers as to tax laws, library support, and the relation of the library to the municipal government follow. Students should be given the idea that the modern library is the schoolhouse for those beyond the schoolhouse doors, a center of civic interest and enterprise, and that librarianship is an active educational force. ${ }^{16}$

\section{Instruction Increases Ability}

Common sense and observation justify the first objective. The inability of many college students to find their way about with assurance in the college library is marked. This is too often the case, despite previously received training. ${ }^{17}$ Nor can it be assumed that the student will repair for himself his deficiencies in this respect. White has pointed out that "the conclusion that college students, left to themselves, fail to learn how to use the library properly is supported by the findings . . . of invesigators." ${ }^{18}$ Louttit and Patrick, in a study of $44 \mathrm{I}$ students of all 4 undergraduate classes, concluded that "knowledge in the use of the library appears to be more closely related to students general ability, as measured by the Ohio State University examinations, than to educational achievements as measured by point-hour ratio." ${ }_{19}$ Reed's study also confirms this finding. On any number of items, upperclassmen made scores that were lower than, practically identical with, or only slightly higher than those made by freshmen. However, Deer's study seems to confirm the hypothesis "that in two years of study the college student acquires a considerable amount of information about the library and its use." In a test administered to freshmen and juniors there was a

16 Smith, op. cit., 98.

17 Reed, op. cit.

18 White, Carl M., "Freshmen and the Library." Journal of Higher Education 8:41, January 1937.

10 Louttit, C. M., and Patrick, J. A., "A Study of

Students' Knowledge in the Use of the Library.."
Journal of Applied Psychology $16: 485$, October 1932. critical ratio of 6 . "This," he concluded, "indicates a rather distinct differentiation between classes at different college levels." 20

Again we have a difference in findings that is probably more seeming than real. It is probable that further investigation will show that uninstructed students acquire some information about and skill in library use, but not enough for really efficient operation on the college level. Instruction is designed to obviate the necessity for students "playing by ear" and under any reasonable circumstances must be more productive than noninstruction. It is likely that the difference in findings was due to the superiority of Deer's testing instrument.

\section{Knowledge of Library Tools}

The second objective is very closely akin to the first, but is not actually identical. This may be seen in the fact that, even when instruction on the elementary and secondary school levels has been successful, study on the college level requires the use of a much more extensive range of bibliographic tools. Knowledge, for example, of the Readers' Guide to Periodical Literature must be supplemented by knowledge of the other indexes; familiarity with the Britannica and Americana must extend to a good many of the subject encyclopedias, as well as to other general ones. The college library card catalog will prove to be a much more formidable tool than those which most freshmen have hitherto used. This objective seems as clearly justifiable as the first.

It is when we get to the third, encouragement of extensive library use, that we arrive at a more debatable issue. One would hardly choose to challenge its general worthwhileness. One is forced, how-

20 Deer, op. cit., 234. 
ever, to ask whether it may be realized through the orientation method, and to question the assumption that underlies it. First of all, there is no positive evidence that it can be realized by this method. Many librarians have, of course, noted that after the inception of the course, freshmen have made a greater use of the library than previous freshmen classes. This, it seems to me, suggests that this increases assurance on the part of the individual student in his ability to use the library for his class assignments, rather than to any development of book or library-mindedness. Studies of library use have persistently indicated that the amount of library use made by college students is relatively meager and that this is true of all four classes, although upperclassmen tend to read and use the library more than underclassmen.

The basic assumption underlying attempts to achieve this objective is that success in studies correlates with extensive use of the library. That is, good students are those who make the most use of the library; therefore, students should be encouraged to use it extensively. But we should note the following remark of Eurich's:

As a special feature of freshman week at the University of Minnesota and throughout the entire first year, attempts have been made to acquaint each student with the college library, the assumption being that once he has familiarized himself with this mine of scholar's resources, he will not only browse among books but dig deeply until he had found truths unsurfaced by the fallacies of casual inspection. Factual evidence to support this claim is rare indeed. ${ }^{21}$

One of the conclusions of his study, "The Significance of Library Reading among College Students," is the degree of relationship between the total amount of reading or amount of reading in the library

\footnotetext{
${ }^{21}$ Eurich, Alvin C. School and Society 36:92', July
}

and either intelligence or scholarship is significant. $^{22} \quad$ A study made nearly ten years later by Thompson and Nicholson does not quite confirm this finding, but also fails to contradict it positively. Their data "seems to indicate that the students of higher scholastic achievement ... probably have a tendency to circulate more volumes." ${ }^{23}$ At least, most studies of this kind indicate, as McDiarmid has said, "the correlation between reading and scholarship is low." 24 Therefore, it seems that efforts to attain this objective by the orientation method are misplaced and should be abandoned. There are other and superior ways of achieving this aim. Strengthening faculty-library cooperation and the improvement of the library's collection and facilities will be two of the best.

The place of the fourth objective in a course in library use instruction seems even more questionable, although it is a proper concern of the library staff. The inculcation of proper study habits-again, an undoubtedly worth-while objective in itselfbelongs elsewhere on the campus in one or more of the traditional classes or in a more largely defined orientation program. It is likely to be less effective when dealt with in the abstract and entirely ineffective in an accelerated course that is concerned with other basic purposes.

It seems logical to conclude that of these four objectives, a course that attempts to instruct freshmen in the use of the library might well attempt only the first two. This conclusion is prompted by two considerations. In the first place, the time given over to it is short and the failure to

(Continued on page 154)

22 Ibid., 96.

${ }_{23}$ thompson, Russell I., and Nicholson, John B. "Significant Influences on General Circulation in a "Significant Influences ,on General Circulation in a January 194I.

24 McDiarmid, E. W., "Conditions Affecting Use of the College Library." Library Quarterly 5:63, January 1935 . 
Waiting several weeks for a book would necessitate a choice between various alternatives, all undesirable - trying to duplicate the research already in print, being frustrated for a month, or breaking the continuity of the research program.

For the scholar at work today there is another reason why the library is indispensable. The world is divided-almost but not wholly. We still get journals from Russia, Poland, Czechoslovakia, and we know that in science the intellectual activity in these countries is intense. The receipt of their journals is one of the effective realities of the present day preventing us from underestimating these separated nations. It is the slender thread of a common interest which must someday grow into a proper understanding. The scholar of course cannot afford to ignore the research behind the iron curtain. He penetrates the iron curtain not by bullets but via the library.

I have spoken of the conventional needs of the student and the scholar for a good library. A word may be added for the value of the library for the few, for those who are seeking to reformulate the philosophy of history and culture, of science and religion. For these the library is indispensable. They must go beyond the platitude that there is no conflict between science and religion. What is needed is an active rapprochement between science and religion, a mutual adjustment of language, a removal of ambiguity, a sober and just recognition by natural science and theology of their common boundaries-not less faith, but more faith, with less doubt as to what is reason and what pretense to reason. The thoughts of St. Augustine must be retraced in their dependence on Plato, and those of St. Thomas with his preference for Aristotle. With a science and logic now available far beyond that of Aristotle, there should be a comparable advance in the form of presentation of religion in its relation to science, and the way in which reason may lead to belief.

For some this may not be necessary; by many others it will not be understood. For the few, the future scientists and philosophers - the potential Whiteheads, Toynbees and Maritains - such a clarification is overdue. For these there is no other approach so consistent with the tenderness, severity and integrity of their minds, or the decisive role which they are destined to play. In some quiet library with its treasures of the past and its record of the present, with its air of otherworldliness, if you please, but with its very real concern with what is to be, the student of today and the scholar of the future may one day bring these things to pass.

\section{Instruction in Library Use}

\section{(Continued from page 144)}

concentrate on one (here considering objectives one and two as a unit) fundamental, realizable aim is likely to result in riding off in all directions at once. The course should eschew anything but the severely practical. Secondly, it is unwise to attempt to accomplish what is better and more easily accomplished elsewhere. It is entirely fitting that librarians wish students to make more use of the library and to adopt more effective methods of study. This concern should, however, take the form of exerting pressures where they will do the most good. If, as seems probable, this instruction has not enjoyed the fullest success on the elementary and secondary school levels, it is also true that there has been only a qualified success on the collegiate. This has been due partly to the lack of definite objectives. 